\title{
An Antipodean History of Interpretation ${ }^{1}$
}

Jack Corbett, School of International, Political and Strategic Studies, ANU

John Boswell, Politics and International Relations, University of Southampton

\begin{abstract}
Elsewhere, especially in Europe and North America, the interpretive approach to political research has emerged as a counter identity. Key figures like Dvora Yanow and Frank Fischer have typically defined and defended interpretivism in opposition to the positivist paradigm they see as dominant in the North American and European contexts. In this paper, we explore the connections between intepretivism's core and its peripheries in both geographical and epistemological terms, by tracing the relationship between interpretivism and Australian political scholarship. In this task, we draw on some of the most celebrated and influential work on Australian politics-by political scientists but before them historians and anthropologists-to show how the approach typically undertaken by these researchers echoes key tenets of interpretivism, especially through an interest in subjective beliefs and experiences, a desire to uncover and bring to life richly contextualised detail, and a commitment to the abductive linking of theory and practice. As such, we suggest that the spread of this counter identity to interpretive researchers in Australia risks manufacturing a sense of methodological antipathy, marginalising the work of interpretivists from mainstream political scholarship.
\end{abstract}

Keywords: interpretivism; Australian politics and policymaking; identity; tradition

\footnotetext{
${ }^{1}$ A slightly amended version of this paper is forthcoming in the September, 2014 issue of the Australian Journal of Public Administration.
} 


\section{Introduction}

At the heart of this essay is a question about the relationship between the core and periphery of an interpretive approach, in both geographic and epistemological terms. That is, we set out to portray the relationships both between interpretivism's Anglo-European core-best exemplified by the annual IPA conference and associated network-and its peripheries, of which Australia and the newly formed Interpretive Policy Analysis Research Group of the Australian Political Studies Association is but one example, and between its epistemological core, hinging on constructivistsubjectivist propositions and qualitative research methods, and its altogether more pragmatic peripheries. When combined, we argue that a picture of two interpretive approaches begins to emerge. The first is a European-focused 'counter identity' that stands in opposition to positivism and the dominance of American behaviouralism in the social sciences. The second incorporates a broad church of scholars who are committed, either explicitly or implicitly, to understanding subjective experiences, documenting rich detail and forms of abductive theorising. In the latter view, interpretivism is a way of thinking about government that might include those from different disciplines - and in this essay we make a special case for history and biography - and ontological perspectives (critical realists, for example, who ask similar questions and adopt similar methods).

Our interest in this dynamic was sparked during what is commonly seen as a rite of passage for Australian PhD students: the presentation of papers on the European conference circuit. Such a tour has many attractions, the most noble among which are the chance to present research to a bigger, and more focused, audience, and the opportunity to rub shoulders with some of the leading scholars in the field. We each attended three conferences (two together) that European summer and this paper is in no small part influenced by our impressions. Two observations stand out. Firstly, we were struck by the repeated surprise of our fellow participants at how far we had travelled to be there. If mentioned only once or twice these comments could be dismissed as idle small talk but the repetition, we believe, reveals something deeper: a lingering European exoticism and curiosity about the Antipodes that extends to its scholarship. Secondly, we were surprised by how strong the sense of an interpretive counter-identity was. It is not that we were naive to the differences between interpetivists and other traditions - quite the opposite. We had read the literature, most cogently put in the writings of Fischer (1998), Schwartz-Shea and Yanow (2006; 2012), and Rhodes and Bevir (2003; 2004). We knew it involved a spirited defence of qualitative, iterative, and meaning-focused research on policy and politics, offering in equal parts a scathing critique of the 'dominant' positivist paradigm and a sophisticated justification for the sort of research that we, and other self-labelling interpretivists, find exciting and important. But we had underestimated the intensity of feeling: to us, the IPA conference in particular resembled a political party convention consumed by this counteridentity.

Both impressions were puzzling. The presence of Antipodeans at such a conference was surely not that unusual? Some of the most influential and cutting-edge work in the interpretive turn comes from scholars operating in Australia, after all (see, just as obvious examples, Rhodes 2011; Colebatch 2009; Bacchi 2009). And while we knew qualitative and constructivist approaches were outside of the mainstream discipline globally, we had assumed this was largely due to the predominance of neo-positivism in the enormous North American scholarly community, and that elsewhere a relatively happy pluralism flourished; this was certainly our impression of the Australian academy, 
where prominent figures in the discipline routinely display interest in interpretive research even if they do not adopt the label for themselves. Our aim in this piece, then, is to explore these impressions further to see if we can make sense of any connection between them.

In doing so, we do not assert that interpretivism is stronger in Australia than elsewhere, but hope to bring to light aspects of work on Australian politics and policy interested in interpretation and consider how they relate to the broader interpretive move. In this endeavour, we first highlight some of the key tenets of interpretivism as outlined by standard-bearers of this identity, before delving into some of the most influential works on Australian politics, policy making, and public administration, both contemporary and classic, to consider how they relate to this interpretive core. In this second task, we are in part retracing important recent work looking inward at Australian political scholarship. Chief among this literature is The Australian Study of Politics (Rhodes 2009), an edited collection commissioned by the Australian Political Studies Association as part of an effort to 'foster a stronger sense of disciplinary identity among political scientists in Australia'. Drawing largely on this work for inspiration and guidance, we have selected a range of authors of tremendous influence on Australian political scholarship to explore in greater detail, uncovering how facets of this work display or anticipate key features of interpretivism. We are not, here, talking about a preference for small-n research conducted using qualitative tools and techniques - this, to a large extent, would be true historically of work on policy and politics everywhere-but more specifically about a broader orientation to the study of politics in Australia of which this is only one small and persistent part. This orientation is one which is focused on: (a) understanding the beliefs and experiences of actors; (b) bringing political stories to life; and (c) reflecting on practice to shed new light on theory.

To be clear, in making these claims, we are not intending to radically re-evaluate the selected authors' scholarship. For the most part our observations align with what the contemporaries, critics and chroniclers of these scholars-and sometimes even the scholars themselves-have asserted. Nor are we so bold as to think we are reimagining the tradition of Australian political science and policy studies as somehow proto-interpretive. In his opening chapter to The Australian Study of Politics, R.A.W Rhodes argues that the discipline is characterised by a mix of traditions-including British interpretive empiricism, European human sciences, and modernist-empiricism inherited from the United States since the 1970s - and that this amalgam has worked against the establishment of any unified identity, counter or otherwise. Our more modest point, then, is that key aspects of this influential scholarship foreshadow or echo the primary features of interpretivism, and that these affinities indicate that interpretivism is far from a radical counter to long-standing norms and ideas about the study of politics and policymaking in Australia.

From this analysis we derive two key arguments. Firstly, we conclude that the interpretive counteridentity has little relevance in an Australian context, although we concede that this may change (in no small part because Australian scholars who wish to publish in overseas journals will need to follow intellectual trends that prevail elsewhere; there is an underlying but often unacknowledged asymmetry here symptomatic of older ideas like the 'cultural cringe'). Secondly, turning the question back on those who inhabit interpretivism's 'core', we argue that on a pragmatic level a narrow counter-identity approach driven by competition in an Australian context is, to borrow from Patrick Weller (2009, p 31), neither 'viable' nor 'pleasant'. The types of affinities we have found mean researchers drawn to an interpretive approach would do better to work pragmatically alongside 
their 'non-believer' peers and colleagues than to assume the interpretive counter-identity wholesale and risk disengaging from the mainstream.

\section{Interpretivism}

The first step towards justifying these claims is to develop a stronger understanding of what interpretivism is and what this approach to the study of politics and policymaking entails. In broad terms, interpretivism represents a turn away from attempting to study the social world as it really is, and towards studying it as it is understood by political actors, and enacted through the beliefs they hold and the cultural norms they practice. The epistemological and ontological underpinnings of the interpretive turn have been the subject of considerable thought and debate elsewhere (see Bevir and Rhodes 2003). Our interest here is more functional than philosophical. We focus on the features that these philosophical commitments manifest in practice, as it is these features we claim have long been observed in Australian political science and policy studies. The particular facets that we highlight in this discussion do not constitute an exhaustive list. Other authors have mapped interpretivism's features out systematically, none more clearly and comprehensively than SchwartzShea and Yanow (2012) in their recent guide on interpretive research design. For parsimony and clarity, we have adapted and narrowed this broader repertoire to place emphasis on three particular features that we see these as being of primary importance to the interpretive approach. These are outlined below.

- Rich detail: First, interpretivism typically involves a commitment to describing and analysing given political phenomena through rich and vivid accounts. Part of the commitment to understanding subjective experience is to capture and recount it in a way that conveys the drama at the heart of political conflict or uncertainty.

- Subjective experience: Perhaps more fundamentally, interpretivism is concerned with the lived, subjective experience of the political actor, whether expressed in public discourse, observed in ethnographic fieldwork, or derived from reflections in interviews. The conceptual basis of this orientation in interpretive manifestos is that this represents the only way of understanding social and political phenomena-that a researcher cannot access the reality of these phenomena independently, and that it is only through the perceptions of the actors involved that any sense can be made of them.

- Abductive logic: Third, interpretivism entails an extension beyond this interest in the rich and vivid portrayal of political phenomena to a greater understanding of their meaning. That is, interpretive research delves into and uncovers novel aspects of practice, but it also relates these findings to theory. The process by which this is done is consistent in orientation with the commitment to exploring subjectivity and uncovering rich contextual detail: it is one of what Schwartz-Shea and Yanow (2012) call 'abductive logic', whereby the researcher 'muses' in iterative, open-ended manner in order to maximise the possibility for creative links between theory and practice.

In the rest of the paper, we aim to show how these features echo or reflect the practices of some of the most influential figures in Australian scholarship in political science and policy studies. Doubtless, these scholars adopted these techniques or ideas for very different reasons or purposes. Where 
interpretivism is consciously ideological, and its practical features clearly elucidated as following a set of principles or commitments, many of the scholars we draw on were or are more pragmatic in orientation, and the features they share in common with interpretivists more a consequence of necessity or common sense. We will draw out these conceptual differences through the body of the paper. What matters more, though, are the commonalities in practice.

\section{Epic histories and vivid accounts}

Narrative and interpretation, two terms synonymous with interpretivism, are staples of historical scholarship, both in Australia and elsewhere. This point has more general importance but is particularly relevant to this discussion as the study of politics in the Antipodean context was, until the post-Second World War period, confined to history departments (Weller 2009, p 20). Consequently, it should come as no surprise that some of the earliest works on Australia's political history share an interpretive interest in conveying vivid detail and 'bringing to life' aspects of politics and policymaking. This tendency is particularly pronounced in the work of political historians, and nowhere among this canon more so than in the collective works of Manning Clark. Indeed, while generally seen as Australia's preeminent historian, Clark taught political science at The University of Melbourne during the Second World War and from the 1950s onwards performed the role of political commentator, public intellectual and self-styled prophet.

Clark is most famous for his six volume $A$ History of Australia, a work in which he explicitly sought to reinterpret the past by seeing the discovery of Australia not as an exclusively British undertaking but as part of a wider historical interaction between Europeans and Asians (Holt 1999, p 98). A History of Australia is essentially a story about how three great ideological faiths - Protestantism, Catholicism and the Secular Enlightenment - shaped the politics of Cold War Australia. In his short history of the man and his work, Stephen Holt (1999, p 109-112) argues that Clark had little time for detached academic discourse and dull empiricism, but instead sought to create a history of Australia in his own image. Indeed, such was his commitment to recreating the drama of political life that he was subject to severe criticism from contemporaries for eschewing the standard textbook narrative. Both sides of politics accused him of abandoning fact in service of a better story. M.H. Ellis famously derided Clark's work as 'history without facts' (for discussion see Moore 1999) while R.W. Connell (1978) complained that Clark's methodology relied too heavily on 'newspapers and literary gents' at the expense of 'the structure of income, the structure of investment, rates of profit or exploitation'. But it was enormously popular - in no small part due to the controversy - in a way that a more specialised monograph would never have been, and it continues to be highly influential in shaping scholarly and popular understandings of Australia's political history.

There are many other aspects of Clark's work that we could highlight here but of particular relevance to this discussion is his connection with biography. Understanding human motivations is a key tenet of an interpretive approach that stands in contrast to the rational-actor models favoured by the behaviouralist tradition, for example. Biography and life writing is one of the primary mediums through which Australian historians, but also journalists and later political scientists, have sought to explore such questions. As Rhodes and Wanna (2009, p 120) highlight, much of the literature on Australian executive politics comes from these sources. Clark was no stranger to biography. At the 
behest of W. K. Hancock, another Australian historian whose work would not be out of place in this discussion, Clark was the inaugural co-editor of the Australian Dictionary of Biography. In addition, like Hancock, who wrote a two-volume biography of the South African statesman Jan Christiaan Smuts, Clark penned In Search of Henry Lawson, a poet, ballardist and symbolic figure of the Australian left, in an attempt to come to grips with his physical, emotional and psychological disintegration. Again, the reviewers pounced, labelling the work as 'a tangled thicket of factual errors, speculation and ideological interpretation' (Holt 1999). The accusation, as before, was that Clark favoured a provocative account over cold facts and dead variables.

But the interest in 'telling a good tale' is not simply reserved for historians writing about Australian politics. It has also been a feature, for instance, of foundational work on public policymaking and administration, a subject often associated with a rather dry and dull analytical approach. This is most clearly exhibited in the influential work of A. F. Davies. As Colebatch (2005) notes in his extensive discussion, Davies is often remembered for his quotable quote about Australians having a 'talent for bureaucracy', but his contribution to scholarly understanding of Australia's public service, and the governance of public problems more generally, is actually remarkably richer. Of the policymaking process in Australian federal politics, for instance, Davies observes:

It is as though there were a political gateway through which all issues pass. Disputed from the moment they are in sight of it and more hotly as they approach - they pass (if they pass) through, and drop out of controversy for a time. Managing the procession are certain 'gatekeepers' not just the Cabinet of the day, but bureaucrats, journalists, association heads and independent specialists camped permanently around each source of problems. To talk of a political process is to recognise some hint of pattern in the way in many different fields the controversial is transformed into the routine (Davies 1964, p 3).

At once, this displays his colourful turn of phrase and interest in the 'aesthetics' of politics (Colebatch 2005), but it also marks a (to that point unheralded) recognition of the multiplicity of actors engaged in the formal process of policy making and an attempt to highlight and subsequently unpack the complexity of the encounters between and among them; it conveys a vibrant and insightful portrait of the policymaking process in Australia and its relationship to interests, power, knowledge and democratic legitimacy.

Among contemporary scholars, this emphasis on re-enacting drama is perhaps most evident in the work of Judith Brett. In her Australian Liberals and the Moral Middle Class, Brett (2003) recounts key moments and periods in the history of Australia's conservative and liberal political parties and movements. She works not just to convey rich detail of episodes like the 1910 Fusion or the establishment of the modern Liberal Party, but to reimagine them for a contemporary audience and situate them within a broader political drama, in the process bringing to life what could have read as a dull institutional chronicle (Dyrenfurth 2005).

Brett's reflections on her own work are instructive. While for many interpretivists, the desire to recount and re-enact the drama of politics and policymaking can be seen to go hand-in-hand with a scepticism about claims to the truth, for the scholars writing in the rich tradition of Australian political history like Brett, the commitment to 'telling a good tale' is less an argument about ontology and more a crucial element of effective scholarship on politics and policymaking. She makes this point explicit in explaining the rationale for her project: 
There are very few books about the Liberal Party, and even fewer ideas. [Current scholarship] fails to provide a coherent and plausible account of the party's role. Yet, without such an account, our understanding of the past hundred years of Australia's history is severely diminished (Brett 2003, p xi)

For her, and for the other scholars cited above, the commitment to vivid detail simply reflects a desire to enrich and enliven our understanding of the stories that have influenced Australia's politics.

\section{Actuating reasons and subjective beliefs}

Related to the goal of providing a rich and vivid account that fosters our understanding of Australian politics is the interpretive desire to provide a sense of the plurality of experiences and perspectives. Indeed, the two are intertwined as a richly nuanced account necessarily canvasses divergent views and ideas even when placing them in the service of a broader narrative or storyline. Like the works outlined above, understanding subjective experiences has a long tradition in historical scholarship. Myra Willard's (1923) famous account of the White Australia policy is an excellent example. Her aim was not so much to recount facts and details of the policy but to understand (and ultimately defend) the sensibilities of the actors involved in bringing this policy into being. Indeed, she devotes an entire chapter to the 'reasons which actuated' the legislation. Although contemporary readers may baulk at her substantive argument, what matters in relation to our discussion is that she draws on public discourse, largely in the form of speeches delivered in legislative assemblies throughout Australia, to develop a sophisticated account of the beliefs of the diverse coalition of actors who supported the policy and how these beliefs influenced the passage and eventual form of this legislation. Her analysis provides important insights into the minds of decision-makers at the time, revealing the pervasive sense of isolation, incohesiveness and vulnerability across the Australian colonies approaching the time of Federation, and how this manifested in a fear of the potential impact of non-European immigration on budding shared values like equality. She concludes:

[Australians] knew that racial unity, though not necessarily racial homogeneity, was essential for national unity, for the national life. The union of a people depends on common loyalty to common ideals... to preserve the unity of their national life, a people can admit emigrants from alien races only if within a reasonable time they show a willingness and a capacity to amalgamate ideally as well as racially with them... They believed that at present nonEuropeans of the labouring classes have neither this willingness nor this capacity (Willard 1923, p 189).

This same orientation has carried through into more contemporary work on Australian politics, although many of these authors refrain from engaging the interpretive counter-identity in justifying or constructing their work. James Walter's (2010) What were they thinking? is an obvious example. Walter makes a finely detailed case for the importance of ideas in shaping Australia's political history, focusing on the subjective beliefs that informed influential leaders throughout the 20th century. In outlining the rationale for his broader project, he explains:

In politics, ideas make a difference.... How will we live together? What is the nature of an individual's entitlements, and obligations? What are the limits of authority? What are the 
elements of the good life? How is community to be sustained? How is achievement to be rewarded, and failure to be penalised? In the end, what principles matter? Every leader, implicitly or explicitly, plays on such themes. They do so, in some respects, because they actually believe in principles and seek ways effectively to act upon them. But they also do so in order to appeal to others who share similar outlooks - they seek to mobilise a following on the path to power (Walter 2010, p 29)

And no discussion of subjectivity and the desire to understand the way that human actors construct their world would be complete without at least one reference to Australian anthropology. After all, while the interpretive move has many influences, including continental philosophy, social anthropology provides much inspiration for both its theory and practice. As with this entire essay, there are numerous examples we could have picked from but, as much for emotional (we have quite literally spent years of our lives working in a building at the ANU which carries his name) as intellectual reasons, we have chosen W. E. H. Stanner.

Stanner's work on Aboriginal religion from the 1930s to 1960s, to paraphrase Robert Manne (2009: 4), represents a withering critique of the prevailing assimilation policy that dominated government thinking on indigenous affairs. His message, developed not just as an academic but as a prominent public intellectual, was clear and uncompromising: Europeans had hopelessly misunderstood the 'primitive' peoples and cultures that they encountered in the Antipodes and this arrogance underpinned the failure of their assimilation policy. There is so much of Stanner's work that is relevant to our argument (the impact of his Boyer Lectures and his reflections on the 'great Australian silence' for instance) but two examples, his essays Durmugam: A Nangiomeri [1959] and The Dreaming [1953], stand out as particularly pertinent to the question of subjectivity. In Durmugam: A Nangiomeri, a piece that Manne (2009, p 4) describes as 'the finest essay by an Australian that I have ever read', Stanner grapples with, amongst other things, the question of murder and legal pluralism. Durmugam had, by his own admission, taken four lives ( $p 27$ ). But, Stanner (2009 [1959], p 37) ponders, is the word 'murder' too pejorative given that the killings could be considered lawful homicide in Aboriginal customary law? Stanner finds in the positive; they conform to the beliefs and practices of the context in which he lived, with subsequent injustice instead arising from the assimilation policy:

The policy of assimilation is meant to offer the Aborigines a 'positive' future-absorption and eventual integration within the European community. Does it involve a loss of natural justice for the living Aborigines? No one answers. Cases like Durmagam's are irritating distractions from loftier things. The policy assumes that the Aborigines want, or will want, to be assimilated; that white Australians will accept them on fair terms; that discrimination will die or can be controlled; that, in spite of the revealed nature of the Aborigines and their culture, they can be shaped to have a new and 'Australian' nature. The chauvinism is quite unconscious. The idea that the Aborigines might reject a banausic life occurs to no one. The unconscious, unfocused, but intense racialism of Australians is unnoticed. The risk of producing a depressed class of coloured misfits is thought minimal, although that is the actual basis from which 'assimilation' begins. (Stanner 2009 [1959], p 43)

In The Dreaming, Stanner (2009 [1953]) pushes us further by highlighting the limits of labels like 'subjectivity' when considering Aboriginal metaphysics and ontology. The overruling mood of The 
Dreaming ('a kind of logos or principle of order transcending everything significant for Aboriginal man' $p$ 58) is one of belief, not of enquiry or dissent:

The Aboriginal does not ask himself the philosophical-type questions: What is 'real'? How many 'kinds' of 'reality' are there? What are the 'properties' of 'reality'? How are the properties 'interconnected'? This is the idiom of Western intellectual discourse and the fruit of a certain social history ... The blacks cite The Dreaming as a chapter of absolute validity in answer to all questions of why and how. In this sense the tales can be regarded as being, perhaps not a definition, but a 'key' of Truth (Stanner 2009 [1953], p 61-62, emphasis in the original).

In this view, interpretations become less about subjective experiences and more about alternate philosophies that question not just the intellectual basis upon which policy is made but, more significantly, the metaphysical assumptions that underpin our analysis of it.

Of course, for these scholars, the interest in subjectivity has not necessarily been based on the same sorts of philosophical presuppositions associated with this orientation in interpretivism. For interpretivists, subjective beliefs and experiences of politics and policymaking are crucial because these scholars hold explicitly that the world can only be understood in these terms: 'Interpretive approaches start with the insight that to understand actions, practices and institutions, we need to grasp the relevant meanings, beliefs and preferences of the people involved' (Bevir and Rhodes in Finlayson et al. 2004). In contrast, for the influential authors on Australian politics and policymaking cited above, those both past and present, exploring subjectivity represents more a common sense way of trying to decipher why and how particular practices came into being. Beliefs, in this context, are not distinct from politics but 'are produced by and serve identifiable interests' (Walter 2010, $p$ 41). Understanding subjectivity, then, is interesting and important not at the exclusion of everything else, but as a vital complement to it.

\section{Unique attributes and abductive logic}

Finally, while for many interpetivists, detailed accounts that seek to understand actors' experiences have an intrinsic value, most of us seek to use this material to make broader theoretical claims about the nature of political life. Abduction is the term interpretivists use to describe their research design where theory and practice are intertwined. There is equally a tradition of iteratively linking the inductive study of political practice in Australia to theoretical notions about politics and policymaking more broadly. This arguably began with the works of William Pember Reeves and Albert Metin respectively on policy and administrative experimentation in Australia and New Zealand in the late $19^{\text {th }}$ and early $20^{\text {th }}$ centuries. Pember Reeves (2011 [1902]), writing partially as historian and partially as participant-observer having served in the fledgling public service in New Zealand in the late $19^{\text {th }}$ century, draws an instinctive comparison with the British and North American experiences in noting the extraordinarily progressive nature of government in Australia and New Zealand around this period:

It might well have looked impossible to organise parties of resistance and progress out of such societies. It might have been fancied, too, that the demand for Government 
interference would be small, and that Australia and New Zealand would be happy hunting grounds for individualism and the philosophic anarchist. Almost the contrary seems coming to pass (Pember Reeves 2011 [1902], p 61).

For him, the puzzle at the centre of his research is why contextual factors which ought to, given foreign experience, lead in one political direction had at that point led in another.

Metin (1977 [1901]), a Tocquevillian visitor from France who recorded his impressions of Australian politics in the early 20th century, approached his subject matter in much the same way. For him, Australia equally represented a mystery that required closer examination. His key observation was that Australia had gone further than any country in pursuing and institutionalising socialist ideals, especially through the key tenets of what Kelly would later dub the Australian settlementcompulsory arbitration and minimum wage standards, tariff protections, state paternalism, imperial benevolence and even White Australia. But it had done so without any obvious political or rhetorical commitment. This represented for him, in the context of brutal ideological conflict raging in parts of Europe at the time, a curious development: Socialism without doctrine.

Of course, the basis of Metin's claims has become subject to scrutiny in more recent times, especially through the work of scholars like Walter (2010) who have done much to uncover the ideological nature of conflict in Australia at the time. Yet Metin's observations represent an important facet of the approach to the study of politics and policy in Australia more broadly in that they are an attempt to make sense of more general political theories in the context of Australian politics, and vice versa, in a recursive, iterative way.

This abductive orientation to studying politics and policymaking in Australia is not something associated solely with the 'birth' of Australian history, either. It has remained an important facet of scholarship in Australian political science and policy studies. One of the most influential contemporary exponents is Patrick Weller, another historian by training, who is almost singlehandedly responsible for the Australian cannon on the executive (in their review of his work, Rhodes and Wanna (2009, p 121-124) dub him the 'narrator-in-chief'). Guided by an interest in practiceWhat do they do? How has it changed? Can they cope? How powerful are they?-Weller's (2001) Australian Mandarins combines publically available sources, including autobiography and biography, with interviews conducted over a twenty year period, to generate a 'collective portrait' of the world of senior government officials. It is not one that consciously tests or builds a theory-indeed his work has been described as eschewing explicit theory (Rhodes and Wanna 2009, p 122)-but it nonetheless entails an engagement with ideas about the 'Westminster model' and the comparative power of the executive in different political contexts. Like Pember Reeves and Metin before him, Weller's in-depth analysis of Australia is fundamentally driven by an interest in practice, but it nevertheless must be seen to be informed by, and equally must be seen to help inform, broader ideas about how politics works.

For interpretivists, abductive logic is associated with a philosophical objection to theory testing. For interpretivists, hypotheses about the social and political world are bound to be wrong or reductive, and researchers should be open to understanding and analysing events as they unfold or from a multiplicity of angles in order to make any illuminating findings. For scholars in the more pragmatic tradition of studying Australian politics, however, the iterative linking of theory and practice is a common sense approach to the area studies in which they have been engaged. It represents an 
obvious and appealing way of linking their observations about Australian politics to political science and policy studies elsewhere, in order to better discern what is special or unique in the Australian context.

\section{Conclusion}

At IPA in 2012 there were two panels on 'Interpretive policy analysis in non-western contexts' in which participants discussed whether interpretivism had a place outside the 'West'. In her reflections on these panels Yanow (2012, p 121) concluded that the 'Western versus non-Western' language 'doesn't capture what we're trying to articulate (nor does "global south" versus "the north")' on the basis that many of the puzzles that interpetivists seek to understand are not geographically determined. For the most part, we agree - whatever 'non-Western' means it seems unlikely that Australia would be included in such a term - but we are not prepared to throw away the line of enquiry altogether. In its place, we have proposed a 'core-periphery' distinction that while capturing something of the geographical divide is not exclusively bound to it. Of course, there are endogenous limits implicit to this binary, too. Certainly, in purely geographical terms, we acknowledge that key figures in the interpretive move - Bevir, Rhodes and Yanow - have written about interpretivism from the 'colonies' (although we think we are on fairly safe ground stating that their main audience remains European). Nevertheless, this move has, we believe, enabled us to shed new light on certain aspects of the interpretive method that have to date only been explored elliptically.

First and foremost, it allows us to highlight the tacit interpretivism that typifies much of the work on Australian politics and policymaking. In the introduction to Rhodes' Festschrif in Public Administration, Wanna and Weller $(2011, \mathrm{p} 2)$ reflect that:

As he converted from behaviouralism to interpretivism (and the word converted is used precisely), he becomes more evangelical in his support of the new ideas than many who might have espoused them far longer, and less vocally.

It is unclear who the 'many' are but we can infer that, in broad terms, it may well include the two of them. Indeed, they have, at various stages, undertaken studies in the same tradition (Rhodes and Weller 2001; Rhodes, Wanna and Weller 2009). In either case, as we have shown, the eminent scholars of Australian politics cited throughout our discussion place emphasis on: (a) exploring subjectivity not as an alternative to explanation, but as part of it; (b) re-enacting drama not as some sort of post-structuralist statement about truth claims, but as a means of producing colourful and meaningful accounts; and (c) abductively linking theory and practice not as a philosophical rejection of hypothesis-testing, but as a common-sense method of exploring Australia's commonalities and differences with other places and other times. In the process, they show that although their work may adopt features of interpretivism, it can do so without displaying the obscurantism or dogmatism that can and often does alienate interpretivists from other scholars of politics and policymaking.

Secondly, assuming the sort of counter-identity glosses over the remarkable willingness of politics and policy scholars from other traditions in Australia to engage with interpretivism either in 
conceptual or methodological terms (eg. Dowding 2004; Marsh 2009), or more commonly in practical terms through collaboration on research issues of common interest.

In recounting these examples, and developing the broader argument, we may be misconstrued as saying that there is no need for scholars of politics in Australia who are interested in uncovering subjective experience, bringing stories to life, or iteratively relating theory and practice to bother much with interpretivism and its conceptual underpinnings. This would be naïve. Australian scholars of politics and policy do not operate in isolation from the rest of the world, and there is a clear need to engage with intepretivism's repertoire of terms, ideas and justifications for international recognition and appeal. But fully assuming the counter-identity associated with this repertoire is unlikely to be helpful or appropriate.

We therefore promote a pragmatic interpretivism that not only better suits the Australian context but provides a more nuanced conceptual basis for interpretivism's 'core' to engage with its 'peripheries'. In this light, new researchers in Australia who are attracted to the interpretive way of studying politics and policymaking like ourselves should understand and be able to trade in the sophisticated language and ideas of this approach, but they should also be able to link this work to its intellectual tradition in the Antipodes. In advocating the broadening of the interpretive church we are suggesting more than simple application of new analytic tools in a derivative way, but are instead continuing and redefining a tradition of Australian scholarship into the present.

\section{References}

Bacchi, C 2009, What is the problem represented to be? Pearson, Sydney.

Bevir, M and Rhodes, RAW 2003, Interpreting British governance, London, Routledge.

Bevir and Rhodes 2004, 'Interpreting British governance' in Finlayson, A 'The interpretive approach in political science: a symposium', British Journal of Politics and International Relations, 6(2), pp 129164.

Brett 2003, Australian Liberals and the moral middle class: from Alfred Deakin to John Howard, Cambridge University Press, Cambridge.

Fischer, F 1998, 'Beyond empiricism: policy inquiry in postpositive perspective', Policy Studies Journal, 26(1), pp 129-146.

Rhodes, RAW (ed) 2009, The Australian study of politics, Palgrave Macmillan, London.

Rhodes, RAW and Wanna, J 2009, 'The executives', in Rhodes (ed) The Australian study of politics, Palgrave Macmillan, London.

Rhodes, RAW, Wanna, J and Weller, P 2009, Comparing Westminster, Oxford University Press, Oxford. 
Rhodes, RAW 2011, Everyday life in British government, Oxford University Press, Oxford.

Colebatch, HK 2005, 'A "talent for bureaucracy": AF Davies and the analysis of government in Australia', Australian Journal of Public Administration, 64(4), pp 32-40.

Colebatch, HK 2009, Policy, $3^{\text {rd }}$ edition, Open University Press, Milton Keynes.

Connell, RW 1978, 'Manning Clark and the Science of History', Meanjin 37, pp 262-268.

Davies, AF 1964, Australian democracy, $2^{\text {nd }}$ edition, Longmans, Melbourne.

Dowding, K 2004, 'Interpretation, truth and investigation: comments on Bevir and Rhodes' in Finlayson, A 'The interpretive approach in political science: a symposium', British Journal of Politics and International Relations, 6(2), pp 129-164.

Dyrenfurth, N 2005, 'Review of Judith Brett's Australian Liberals and the moral middle class: from Alfred Deakin to John Howard', History Australia, 2(2), p 172.

Holt, S 1999, A short history of Manning Clark, Allen \& Unwin, Sydney.

Marsh, D 2009, 'Keeping ideas in their place: in praise of thin constructivism', Australian Journal of Political Science, 44(4), pp 679-696.

Metin, A 1977 [1901], Socialism without doctrine, Ward, R (trans), Alternative Publishing Cooperative, Chippendale, NSW.

Moore, A 1999, "'History without Facts": MH Ellis, Manning Clark and the Origins of the Australian Dictionary of Biography', Journal of the Royal Australian Historical Society, 85, pp 71-84.

Pember Reeves, W 2011 [1902], State experiments in New Zealand and Australia, volume 1, Cambridge University Press, Cambridge.

Schwartz-Shea, P and Yanow, D 2012, Interpretive research design: concepts and processes, Routledge, New York.

Stanner, WEH 2009 The Dreaming and other essays, Manne, R (ed), Black Inc. Agenda: Collingwood, Vic

Wanna, J and Weller, P 2011, 'The irrepressible Rod Rhodes: contesting traditions and blurring genres', Public Administration, 89(1), 1-14.

Walter, J 2010, What were they thinking? The politics of ideas in Australia, UNSW Press, Sydney.

Weller, P 2009, 'Universities and the study of politics' in Rhodes (ed) The Australian study of politics, Palgrave Macmillan, London.

Willard, M 1923, History of the White Australia policy to 1920, Melbourne University Press, Melbourne.

Yanow, D and Schwartz-Shea, P (eds) 2006, Interpretation and method: empirical research methods and the interpretive turn, ME Sharpe, New York. 